\title{
A Group of French Books
}

THE Library's constant growth in variety as well as in physical size is nicely illustrated by the recent acquirement of the three books which form the subject of this article. Not only is a very wide range of American material available, but also we are reaching out into other lands and other times.

Froumonteau's Le Secret des finances de France descouvert et départi was first published in octavo in I59I. The Library has obtained the second and enlarged edition, published the same year. Its firm old parchment binding would be an ornament to any bookshelf, and the edges of old manuscript with which it was 'backed' add a provocative element of attraction. Among the earliest of French statistical works, it is designed to give a survey of the losses occasioned to France by the Wars of Religion. These are set down with the utmost precision. The number of cities and villages destroyed, soldiers and inhabitants killed, 'les femmes et filles violées,' are all carefully indicated. There is much incidental information on the general economic conditions of France in the sixteenth century.

The same remark applies to the second of the group, the Récherches et considerations sur les finances de France depuis l'année 1595 jusqu'a l'année 1721 (2 vols. in $4^{\text {to }}$ Basle, $175^{8}$ ). The author is François Veron-Duverger de Forbonnais (I722-1800), a wellknown French economist. Forbonnais was also an official under Louis $\mathrm{XV}$, but in $\mathrm{I} 763$, consequent on his proposal of certain financial reforms which touched the privileged classes, he was forced to retire. His life of enforced leisure doubtless brought good out of evil in the shape of his other writings. The Récherches is scientific and scholarly and a rare book in America.

The third item is, in some respects, the most interesting of all. It is a manuscript, bound in leather, entitled Traité sur l'utilité et la necessité des chemins publics et les moyens de les executer. No author is indicated and apparently the work was never published. Internal evidence fixes the date roughly at about $\mathrm{I} 760$. The subject of roads and road-making is discussed from various angles - engineering, industrial, political - for the most part ably, and clearly. The author is a forerunner of men such as Brindley and Macadam who were shortly to revolutionize transportation.

These three books, while not exactly chosen at random, are but 
selections from the stream that is pouring in. All three of them are relatively scarce, all three are valuable to the student, and all, especially the first and third, have an interest for the bibliophile.

\section{A Mountain-Climbing Canal}

Something of the determination with which Massachusetts, and particularly Boston, waged the struggle for connection with the West, that is to say, for existence, is mirrored in a rather scarce state document which the Society possesses. The "Report of the Commissioners of the State of Massachusetts on the Routes of Canals from Boston Harbor to the Connecticut and Hudson Rivers" (Boston, I 826) conceals, beneath a mass of engineering data, a vivid story of New England's past.

In colonial days, and for a generation beyond, wealth and progress was on the sea. Many ports vied with each other for preeminence and not until comparatively late was it decided that Boston, rather than Marblehead or Newport, R. I., was to be the metropolis. Then came manufacturing, slowly at first, but spreading over the countryside as markets slowly widened. Efforts of the rival ports to aggrandize themselves at the expense of competitors are seen in such undertakings as Boston's Middlesex Canal, designed specifically to drain the trade of the upper Merrimac away from its natural outlet at Newburyport.

In 1825 , the Erie Canal was opened. It was a threat at New England's prosperity, which, if not met, would prove fatal. Connection with the back country there must be, or she would perish. At first, there seemed to be little prospect of meeting the challenge. As a forlorn hope, under the direction of the celebrated engineer, Loammi Baldwin, the survey described in the report was made of a route for a canal between Boston and the Hudson. No trifling duck pond was too small to be noticed, nor did an intervening mountain range daunt the engineer, though his plan for floating barges over mountain tops must remain as a monument to optimism. "The height of the summit level, in the gorge of the Green Mountain has been barometrically ascertained to be 870 feet above the surface of Hoosack River, but it may be less above the Deerfield at the Great Bend." "To pass this stupendous mountain, two modes present themselves: the one by locks, and the other by piercing it with a tunnel." The engineer after much calculation, decided in favor of a 